\title{
BODY MASS INDEX DAN KAITANNYA DENGAN DIABETES MELITUS PADA UMUR $\geq 15$ TAHUN DI INDONESIA, STUDI DATA INDONESIAN FAMILY LIFE SURVEY V
}

\author{
Body Mass Index And its Relationship with Diabetes Mellitus in Age > 15 Years in Indonesia, \\ Indonesian Family Life Survey V Data Study \\ ${ }^{1}$ Purwo Setiyo Nugroho, ${ }^{2}$ Anisa Catur Wijayanti \\ ${ }^{1}$ Program Studi Kesehatan Masyarakat, STIKes Kapuas Raya, Sintang \\ ${ }_{2}^{2}$ Program Studi Kesehatan Masyarakat, Universitas Muhammadiyah Surakarta \\ Email:purwo.skm@gmail.com
}

\begin{abstract}
World Health Organization predicts that the number of diabetics in Indonesia will be ranked fifth in 2025 with a prediction of the number of people as many as 12.4 people. Body mass index is one of an indicator of obesity with diabetes mellitus in Indonesian. This study aims to determine the association of obesity with diabetes mellitus in the survey respondents Indonesian Family Life Survey V. This study is a study of secondary data analysis of Indonesian Family Life Survey V conducted by Cross-Sectional approach. The population in this study was 48,139 respondents, but after cleaning data with the aim to remove the missing data than the number of respondents as much as 30.133 with the study group aged over 15 years. Chi-square analysis states that there is a relationship between obesity with diabetes mellitus with p.value 0,000 and OR value of 3.377; CI 95\% 2,602-4,383. It can be concluded that obesity has an opportunity for the occurrence of diabetes mellitus disease 3.377 times compared to people who do not suffer from obesity. Obesity factor is one of the predisposing factors to increase blood sugar which is an indicator of diabetes mellitus. Pathologically this is because the cells of Langerhans island beta become less sensitive to stimuli due to blood sugar levels and obesity (obesity) will suppress the number of insulin receptors in the cells throughout the body.
\end{abstract}

Keywords: Diabetes Mellitus, Obesity, IFLS

\begin{abstract}
Abstrak
World Health Organization memprediksi bahwa jumlah penderita diabetes di Indonesia akan menduduki peringkat ke lima pada tahun 2025 dengan prediksi jumlah penderita sebanyak 12,4 jiwa. Indeks masa tubuh merupakan salah satu indikator obesitas dengan diabetes melitus pada penduduk Indonesia. Penelitian ini bertujuan untuk mengetahui kaitan obesitas dengan diabetes mellitus pada responden survei Indonesian Family Life Survey V. Penelitian ini merupakan penelitian analisis data sekunder Indonesian Family Life Survei V yang dilakukan dengan pendekatan Cross Sectional. Populasi pada penelitian ini sejumlah 48.139 responden, namun setelah data di cleaning dengan tujuan untuk menghapus data yang missing maka didapatkan jumlah responden sebanyak 30.133 dengan kelompok penelitian berdasarkan usia diatas 15 tahun. Hasil analisis Chi square menyatakan bahwa terdapat hubungan antara obesitas dengan diabetes melitus dengan nilai p.value 0,000 dan nilai OR 3,377; CI 95\% 2,6024,383. Dapat disimpulkan bahwa obesitas memiliki peluang untuk terjadinya sakit diabetes melitus sebesar 3,377 kali dibandingkan dengan orang yang tidak menderita obesitas. Faktor obesitas merupakan salah satu faktor prediposisi untuk meningkatkan gula darah yang merupakan sebuah indikator diabetes melitus. Secara patologi hal ini dikarenakan se-sel beta pulau Langerhans menjadi kurang peka terhadap rangsangan akibat kadar gula darah dan kegemukan (obesitas) akan menekan jumlah reseptor insulin pada sel-sel seluruh tubuh.
\end{abstract}

Kata kunci : Diabetes Melitus, Obesitas, IFLS 


\section{PENDAHULUAN}

Globalisasi yang terjadi saat ini memiliki dampak positif bagi pembangunan sebuah negara untuk berkembang, namun disisi lain dampak negatif terjadi pada sektor kesehatan terutama pada permasalahan berkurangnya aktivitas fisik dikarenakan semakin canggihnya alat yang dapat mempermudah kegiatan sehari-hari dan maraknya makanan cepat saji yang tersebar tidak hanya di kota besar tetapi juga di daerah di negara ini. Kondisi ini dapat mengakibatkan risiko terjadinya kelebihan berat badan (overweight) yang diakibatkan konsumsi makanan cepat saji dan kurangnya aktivitas fisik sehari-hari.

Sebuah fakta dari Riset Kesehatan Dasar (Riskesdas) tahun 2007 hingga 2010 membuktikan bahwa prevalensi overweigt dan obesity di Indonesia pada umur dewasa semakin meningkat dari 19,8\% pada 2007 hingga 23\% pada 2010 (Rachmi dkk., 2017). Hal ini menguatkan bahwa risiko terjadinya penyakit tidak menular akibat obesitas juga akan meningkat. Salah satu risiko akibat obesitas adalah diabetes melitus, sesuai dengan penelitian yang dilakukan oleh Arif dkk (2014) menyatakan bahwa terdapat hubungan antara obesitas dengan kadar gula darah puasa pada pegawai sekretariat daerah Privinsi Riau. Kadar gula darah yang merupakan indikator dalam penentuan penyakit diabetes melitus.

World Health Organization memprediksi bahwa jumlah penderita diabetes di Indonesia akan menduduki peringkat ke lima pada tahun 2025 dengan prediksi jumlah penderita sebanyak 12,4 jiwa (Arif dkk., 2014). Hal ini perlu menjadi sebuah perhatian seluruh pihak agar saling bekerjasama dalam meminimalisir risiko-risiko terjadinya diabetes melitus. Penelitian ini memberikan informasi terkait kaitan indeks masa tubuh yang merupakan indikator obesitas dengan diabetes melitus pada penduduk Indonesia menurut data Indonesian Familit Life Survey V. Penelitian ini bertujuan untuk mengetahui kaitan obesitas dengan diabetes mellitus pada responden survei Indonesian Family Life Survey V.

\section{BAHAN DAN METODE}

Penelitian ini merupakan penelitian analisis data sekunder Indonesian Family Life Survei $V$ yang dilakukan dengan pendekatan Cross Sectional dimana dalam desain ini pengukuran dilakukan dalam satu waktu. Populasi pada penelitian ini sejumlah 48.139 responden, namun setelah data di cleaning dengan tujuan untuk menghapus data yang missing maka jumlah responden sebanyak 30.133 dengan kelompok penelitian umur diatas 15 tahun. Analisis data dilakukan dengan menggunakan software komputer untuk mempermudah dalam interpretasi data. Analisis penelitian dilakukan menggunakan analisis chi square yang dapat mengestimasi peluang terjadinya sebuah masalah.

\section{HASIL DAN PEMBAHASAN}

Hasil analisis distribusi frekuensi berdasarkan karakteristik responden berupa jenis kelamin dan umur serta distribusi frekuensi variabel diabetes melitus dan variabel obesitas.

Tabel 1. Distribusi Frekuensi Karakteristik Responden

\begin{tabular}{ccc}
\hline Karakteristik Responden & & \\
\hline Jenis Kelamin & $\mathbf{n}$ & $\%$ \\
$\quad$ Laki-Laki & 14.118 & 46,9 \\
Perempuan & 16.015 & 53,1 \\
Umur & $\mathbf{n}$ & $\%$ \\
$\quad \geq 40$ tahun & 12.275 & 40,7 \\
$\quad<40$ tahun & 17.858 & 59,3 \\
\hline
\end{tabular}

Tabel 2. Distribusi Frekuensi Diabetes Melitus dan Kategori berat badan lebih

\begin{tabular}{lcc}
\hline Variabel & & \\
\hline Diabetes Melitus (DM) & $\mathbf{n}$ & $\mathbf{\%}$ \\
$\quad$ Sakit DM & 229 & 0,8 \\
$\quad$ Tidak Sakit DM & 29.904 & 99,2 \\
Obesitas & $\mathbf{n}$ & $\%$ \\
$\quad$ Obesitas & 6.536 & 21,7 \\
$\quad$ Tidak Obesitas & 23.597 & 78,3 \\
\hline
\end{tabular}

Berdasarkan tabel 1 hasil analisis frekuensi pada jenis kelamin menunjukkan bahwa responden terbanyak adalah perempuan dengan persentase sebesar 53\%. Sedangkan karakteristik umur responden terbanyak umur $<40$ tahun, untuk kelompok umur dalam penelitian ini yakni kelompok 
umur $\geq 15$ tahun sebab terdapat kriteria ekslusi dalam penelitian yang tidak mengikutkan kelompok umur $<15$ tahun.

Berdasarkan tabel 1 menjelaskan bahwa responden terbanyak dalam penelitian ini merupakan sebagian besar perempuan sejumlah 16.015 responden (53,1\%). Perempuan memiliki risiko tinggi terjadinya diabetes melitus karena kehamilan memiliki risiko terjadinya diabetes melitus, selain itu wanita memiliki peluang memiliki risiko memiliki indeks masa tubuh yang lebih besar (Allorerung dkk., 2016). Berdasarkan tabel 1 menjelaskan bahwa responden terbanyak berada pada umur $<40$ tahun, namun risiko terjadinya diabetes melitus semakin meningkat seiring meningkatnya umur mulai dari umur 35 tahun (Soetiarto dkk., 2010).

Berdasarkan tabel 2 hasil analisis frekuensi pada variabel diabetes melitus menunjukkan bahwa responden yang sakit diabetes melitus sebanyak 229 $(0,8 \%)$, penentuan kategori diabetes melitus berdasarkan pada riwayat mengkonsumsi obat diabetes melitus. Sedangkan pada variabel obesitas, didapatkan bahwa responden yang obesitas sebanyak $6.536(21,7 \%)$, penentuan kategori obesitas berdasarkan perhitungan Indeks Masa Tubuh $\left(\mathrm{Kg} / \mathrm{m}^{2}\right)$.

Tabel 3. Body Mass Index dan Kaitannya dengan Diabetes Melitus pada Umur $\geq 15$ tahun di Indonesia (Studi Data Indonesia Family Life Survey V).

\begin{tabular}{lccccc}
\hline Variabel & \multicolumn{2}{c}{ Diabetes Melitus (DM) } & p.value & OR & 95\% CI \\
\hline Obesitas & Sakit DM & Tidak Sakit & & & \\
& & DM & 0,000 & 3,377 & $2,602-4,383$ \\
Obesitas & 110 & 6.426 & & & \\
Tidak Obesitas & 119 & 23.478 & & & \\
\hline
\end{tabular}

Berdasarkan hasil analisis tabulasi silang penelitian pada tabel 3 didapatkan bahwa responden yang menderita obesitas dan sakit DM sebanyak 110 responden. Analisis Chi square menyatakan bahwa terdapat hubungan antara obesitas dengan diabetes melitus dengan nilai $p$. value 0,000 dan nilai OR 3,377; CI 95\% 2,602-4,383. Dapat disimpulkan bahwa obesitas memiliki peluang untuk terjadinya sakit diabetes melitus sebesar 3,377 kali dibanding orang yang tidak menderita obesitas, serta berdasarkan nilai CI $95 \%$ hasil penelitian ini signifikan. Hal ini diperkuat dengan penelitian yang dilakukan oleh Soetiarto dkk (2010) menyatakan bahwa obesitas memiliki risiko terjadinya diabetes melitus sebesar 2,26 kali untuk terjadinya diabetes melitus.

Faktor obesitas merupakan faktor predisposisi untuk meningkatkan gula darah yang merupakan sebuah indikator diabetes melitus. Secara patologi hal ini dikarenakan se-sel beta pulau Langerhans menjadi kurang peka terhadap rangsangan akibat kadar gula darah dan kegemukan (obesitas) akan menekan jumlah reseptor insulin pada sel-sel seluruh tubuh. Kadar gula darah dipengaruhi pula oleh faktor herediter, aktivitas fisik, asupan diet, keluaran energi, metabolisme dan hormonal. Peningkatan glukosa dan lemak akan mengakibatkan transportasi asam lemak yang kedalam adipose dan lipogenesis meningkat. Program olah raga yang baik dan terukur akan menstabilkan kadar gula darah (Purwandari, 2014).

Hasil analisis chi square diatas merupakan hasil analisis antar dua variabel saja dan tidak mempertimbangkan variabel lainnya. Sehingga nilai OR yang didapatkan bukan merupakan nilai yang sebenarnya, sehingga nilai OR yang didapatkan berisiko merupakan nilai yang overestimate maupun underestimate. Hal ini merupakan sebuah bias yang mempengaruhi kualitas sebuah hasil penelitian.

\section{KESIMPULAN DAN SARAN}

Berdasarkan hasil penelitian ini didapatkan bahwa terdapat hubungan antara obesitas dengan diabetes melitus. Pengukuran variabel obesitas menggunakan alat ukur yang valid (timbangan badan dan alat ukur tinggi badan), namun untuk pengukuran variabel diabetes melitus hanya sekedar 
menanyakan riwayat konsumsi obat diabetes melitus, sehingga berpotensi tinggi bias informasi. Selain itu, hasil penelitian juga tidak dilakukan kontrol variabel lainnya, sehingga berisiko besar untuk terjadinya overestimate maupun underestimate nilai OR penelitian. Pengukuran diabetes melitus sebaiknya menggunakan alat ukur biomedis sehingga dapat terukur dan valid, serta pada penelitian selanjutnya menggunakan variabel kontrol dan analisis multivariat untuk mendapatkan nilai OR yang sebenarnya.

\section{DAFTAR PUSTAKA}

Allorerung, Desy L., Sekeon, Sekplin A.S., Joseph, Wooford B.S., 2016. Hubungan Antara Umur, Jenis Kelamin dan Tingkat Pendidikan dengan Kejadian Diabetes Melitus Tipe 2 di Puskesmas Ranotana Weru Kota Manado Tahun 2016. Availablefrom:http://medkesfkm.unsrat.ac.id /index.php/hubungan-antara-umur-jenis kelamin-dan-tingkat-pendidikan-dengankejadian-diabetes-melitus-tipe-2-dipuskesmasranotana-weru-kota-manado-tahun-2016/

Arif M, Ernalia Y, Rosdiana D., 2012. Hubungan Indeks Massa Tubuh dengan Kadar Glukosa Darah Puasa pada Pegawai Sekretariat Daerah provinsi Riau. J Online Mhs Univ Riau [Internet]. 2014;1(2). Available from: http://jom.unri.ac.id.

Purwandari, H., 2014 Hubungan Obesitas Dengan Kadar Gula Darah Pada Karyawan Di Rs Tingkat Iv. Ef Issn 0854-1922. 2014;1:65-72

Rachmi CN, Li M, Alison Baur L., 2017. Overweight and obesity in Indonesia: prevalence and risk factors - a literature review. Public Health. 2017;147:20-9.

Soetiarto, Farida, Roselinda S., 2010. Hubungan Diabetes Mellitus dengan Obesitas Berdasarkan Indeks Massa Tubuh dan Lingkar Pinggang Data Riskesdas 2007. Bul Penelit Kesehat. 2010;38(1):36-42. 